\section{RESPONSE TO WARAKAGODA SIRIVARDANA, 2009}

S.W. Kotagama ${ }^{1}$, Rex I. De Silva², A. S. Wijayasinha $^{1}$ and V. Abeygunawardana ${ }^{1}$

${ }^{1}$ Field Ornithology Group of Sri Lanka, Department of Zoology, University of Colombo, Sri Lanka

E-mail: fogsl@slt.lk

2 Seabird Watch (Sri Lanka), 31, Dampe, Madapatha 10306, Sri Lanka

We respond to the article by Deepal Warakagoda and Udaya Sirivardana entitled "The Avifauna of Sri Lanka: An Overview of the Current Status” (2009). In an appendix to this article the writers make several critical comments on the "Avifaunal List of Sri Lanka”, authored by us (Kotagama, et al., 2006). Warakagoda and Sirivardana contend that many species are included in our publication "Which had not been accepted by the CBCRRC [Ceylon Bird Club Records and Rarities Committee], and reports whose contents fall short of the level of authenticity required by a standard rarities committee”. It goes on to say that "A clearly inadequate criterion is used for accepting sight records of rare migrants”.

A single example will serve to totally refute their allegations. In 1983 and again in 1990 White-cheeked Tern Sterns repressa were observed in Sri Lanka. The CBCRRC however did not accept that the species occurs in the Island and the Ceylon Bird Club (CBC) Checklist of the Birds of Sri Lanka (Wijesinghe, 1994) relegated the sightings to an appendix of rejected species considered to have been "Reported doubtfully”. In contrast the Field Ornithology Group of Sri Lanka (FOGSL) recognized that the Whitecheeked Tern occurs in the Island and included the species in its publications. The writers subsequently included the White-cheeked Tern in their "Avifaunal List of Sri Lanka” (Kotagama et al., 2006). Twentyfive years after the first sighting, a White-cheeked Tern was captured in Bundala on 13 December 2008. The bird was measured, photographed, ringed and released. This clearly substantiated the reliability of our criteria. Images of the bird were disseminated widely in ornithological literature and the internet. Subsequently a second specimen was also captured and ringed. This confirms beyond any reasonable doubt that White-cheeked Terns do visit Sri Lanka. Despite this compelling evidence, the "CBC Sri Lanka List (Country List) of Bird Species” omits the Whitecheeked Tern (see CBC website). This raises serious doubts relating to the reliability and validity of the methodology adopted by the CBCRRC where it appears that clearly inadequate criteria, which lack a level of authenticity, are used for assessing and validating records of rare migrants.

It is necessary to clarify that although Warakagoda and Sirivardana's article may give some readers the (incorrect) impression that the CBCRRC is the ultimate authority on ornithological matters in Sri Lanka, this is emphatically not the case. The CBCRRC does not have any official status outside the CBC (c. 95 members). It does not represent the majority of Sri Lankan ornithologists and its decisions are not recognized by Sri Lanka's largest ornithological organization, the Field Ornithology Group of Sri Lanka (membership c. 900+).

We have outlined clearly the criteria adopted by us in the "Avifaunal List of Sri Lanka" (Kotagama et al., 2006); hence, there should really be no grounds for confusion or unwarranted criticism. The fact is that the FOGSL criteria and list are accepted by the majority of Sri Lankan ornithologists and birders, as well as by global organizations such as BirdLife International.

\section{Literature cited}

CBC web site: http://www.ceylonbirdclub.org/sri-lankabird-list.php (Accessed on 22 May 2011)

Kotagama, S. W., R. I. De Silva, A. S. Wijayasinha and V. Abeygunawardane, 2006. Avifaunal List of Sri Lanka. In: Bambaradeniya, C. N. B. (Ed.) The Fauna of Sri Lanka: Status of Taxonomy, Research and Conservation. The World Conservation Union and Government of Sri Lanka, Colombo. 164-203.

Warakagoda, D. and U. Sirivardana. 2009. The Avifauna of Sri Lanka: An Overview of the Current Status. Taprobanica, 1 (1): 28-35.

Wijesinghe, D. P. 1994. Checklist of the Birds of Sri Lanka. Ceylon Bird Club, Colombo: 49. 